\title{
Superheroines and Sexism: Female Representation in the Marvel Cinematic Universe
}

\author{
Folukemi Olufidipe $^{1}$, Ms. Yunex Echezabal ${ }^{1}$ \\ ${ }^{1}$ Doral Academy Charter High School, Miami, FL, USA \\ DOI: https://doi.org/10.47611/jsrhs.v10i2.1430
}

\section{ABSTRACT}

The Marvel Cinematic Universe (MCU) is the highest-grossing film franchise of all time and since the premiere of Iron Man in 2008, it has risen to fame as a source of science-fiction entertainment. Sexism in the film industry often goes brushed aside but the widespread success of Marvel Studios calls attention to their treatment of gender roles. This paper explores the progression of six female superheroes in the MCU and what effect feminist movements have had on their roles as well as upcoming productions in the franchise. This paper used an interdisciplinary, mixedmethods design that studied movie scripts and screen time graphs. $14 \mathrm{MCU}$ movies were analyzed through a feminist film theory lens and whenever a female character of interest was chosen, notes were taken on aspects including, but not limited to, dialogue, costume design, and character relationships. My findings showed that females in the MCU are heavily sexualized by directors, costume designers, and even their male co-stars. As powerful as some of these women were found to be, it was concluded that Marvel lacks in female inclusivity. Marvel's upcoming productions, many of which are female-focused, still marginalize the roles of their superheroines which is a concern for the future of the film industry. Marvel is just one franchise but this study shows how their treatment of female characters uphold patriarchal structures and perpetuate harmful stereotypes that need to be corrected in the film industry as a whole.

\section{Introduction}

The Marvel Cinematic Universe (MCU) consists of a series of superhero films produced by Marvel Studios to bring forth the stories of some of the most legendary superheroes known to date. Since its debut in 2008, the MCU has grossed over $\$ 12$ billion in global ticket sales making itself the highest-grossing film franchise of all time (Gerard and Poepsel, 27). Marvel Studios releases its films in groups called "Phases" using pivotal movie release years as cutoffs. Phase One began in 2008 with the release of Iron Man and Phase Three concluded in 2019 when Spider-Man: Far From Home premiered. Collectively, Phases One through Three are known as the "Infinity Saga." Considering the widespread success of Marvel Studios' movies and the feminist movements defining the 2000s era, it is worth exploring how certain female roles have progressed throughout the development of the MCU and what effect fourth-wave feminism has had on Marvel Studios' decision to become more female-forward in the upcoming Phase Four that will commence in November 2020 with the premiere of Black Widow.

Throughout this paper, I will be discussing six female characters within the Marvel Universe who I believe have shown the most progression in their roles since their debut. Virginia "Pepper" Potts is the CEO of Stark Industries, a company formerly run by her late husband, Tony Stark, also known as Iron Man. Pepper's minor role as Tony's assistant turned CEO and eventually superheroine when she makes her debut as Rescue in Avengers: Endgame represents one of the most complex yet underrepresented female character developments in the MCU. Black Widow/Natasha Romanoff was raised in a Russian training program that transformed her into a lethal undercover agent (Bateman, 1). Starring in ten movies throughout the Infinity Saga, Black Widow was the only female in the Avengers group until her unexpected death in Avengers: Endgame. As a product of genetic experimentation by HYDRA, a criminal 
paramilitary organization, Scarlet Witch/Wanda Maximoff uses her enhanced abilities to fight for what she believes is right in the world. Fueled by her dark past and emotional struggles, Scarlet Witch's unique powers give her one of the most valuable roles in the Marvel Universe, especially in Avengers: Age of Ultron and Avengers: Infinity War. Gamora was a trained assassin raised by her adoptive father Thanos in Outer Space. When his destructive wrath led her to turn against him, she joined the Guardians of the Galaxy and fought with them until Thanos sacrificed her life in Avengers: Infinity War. Also raised by Thanos, Nebula trained alongside her "sister" Gamora to become one of the deadliest assassins in the galaxy. Finally, Captain Marvel/Carol Danvers became one of the most powerful heroes known to the universe after fighting for the Kree during an intergalactic war in the 1990s. She then turned against her own race after discovering that they suppressed the full extent of her powers, which she then uses to defend the galaxy and eventually aid the Avengers in their fight against Thanos in Avengers: Endgame.

In the same way that the collection of MCU movies are categorized by phases, the ongoing feminist movement is comprised of waves. Each wave signifies a distinct demand for change and call to action by the women oppressed during its respective era. Sparked by a political agenda fighting for property and voting rights, the first wave of feminism spanned from the 1830s to the early 1900s. Second-wave feminism arose during the post World War II era when women sought workplace and reproductive rights. Third-wave feminism, from the 1990s to the early 2000s, continued efforts to close wage gaps and improve reproductive rights for women (Dorey-Stein). In 2012, the fourth wave of feminism emerged and as of today, a new generation of feminists use social media platforms to address sexual harassment concerns and workplace discrimination (Burkett and Brunell).

This analysis involves the amalgamation of feminism, sexism, and elements of film in order to redefine the fantasy of the Marvel Cinematic Universe as an academic topic of discussion. Scholarly research has yet to be conducted regarding the MCU's female inclusivity analyzing the aforementioned characters as a whole. For this reason, this paper is the first to contribute to the lack of discussion on such a unique topic. Although this paper only focuses on one film franchise, the implications of this research are not limited to the MCU and its characters. This paper aims to situate the roles of Marvel females within the broader context of the upcoming Phase Four, fourth-wave feminism, and the overall film industry.

\section{Methods}

The first step in answering this question was to select which characters I would research. Having distinct roles throughout all three Phases, the six females chosen were determined to be the most prominent and involved in the MCU. A color-coded spreadsheet was created to determine which movies each female character starred in. Shown in Table 1, the chart has every movie that needed to be watched to collect the necessary data (any white space indicates that the character did not appear in that film). Each film was watched several times and thorough notes were taken whenever a character of interest appeared on the screen. Some specific points for analysis were the individual characterization of each female and how their traits related to the plot, their actions and dialogue with their male counterparts, romantic vs. platonic relationships, as well as costume design (Jacobs, 6-7). During a fight scene, the use of their powers and their origin were also documented. Combined with a close reading of original movie scripts and directorial cues guided by film theory texts, this analysis uses an interdisciplinary, mixed-methods design. A mixed-methods design broadens the results of this research to have several purposes for application to the real world (Hesse-Biber, 7). The blend of qualitative data from personal interpretation of movie notes as well as quantitative data (see screen time graphs in "Findings") allows for the expansion of the context of this study. 
Table 1. Color-coded spreadsheet of the six characters and which movies they appear in.

\begin{tabular}{|c|c|c|c|c|c|c|c|}
\hline *mention & $* *$ credits & $\begin{array}{l}\text { Pepper } \\
\text { Potts }\end{array}$ & $\begin{array}{l}\text { Black } \\
\text { Widow }\end{array}$ & $\begin{array}{l}\text { Scarlet } \\
\text { Witch }\end{array}$ & Gamora & $\begin{array}{l}\text { Captain } \\
\text { Marvel }\end{array}$ & Nebula \\
\hline \multicolumn{8}{|c|}{ Iron Man (2008) } \\
\hline \multicolumn{8}{|c|}{ Iron Man 2 (2010) } \\
\hline \multicolumn{8}{|c|}{ The Avengers (2012) } \\
\hline \multicolumn{8}{|c|}{ Iron Man 3 (2013) } \\
\hline $\begin{array}{r}\text { Captain A } \\
\text { So }\end{array}$ & $\begin{array}{l}\text { ica: The Winter } \\
\text { r (2014) }\end{array}$ & & & $* *$ & & & \\
\hline \multicolumn{8}{|c|}{ Guardians of the Galaxy (2014) } \\
\hline Avengers: & of Ultron (2015) & $*$ & & & & & \\
\hline Captain & $\begin{array}{l}\text { rica: Civil War } \\
\text { 16) }\end{array}$ & $*$ & & & & & \\
\hline \multicolumn{8}{|c|}{$\begin{array}{c}\text { Guardians of the Galaxy } 2 \\
(2017)\end{array}$} \\
\hline Spider-1 & $\begin{array}{l}\text { Homecoming } \\
\text { 17) }\end{array}$ & & $*$ & & & & \\
\hline \multicolumn{8}{|c|}{ Thor: Ragnarok (2017) } \\
\hline \multicolumn{8}{|c|}{ Avengers: Infinity War (2018) } \\
\hline Captai & arvel (2019) & & $* *$ & & & & \\
\hline Avenger & Idgame (2019) & & & & & & \\
\hline
\end{tabular}

The fairly recent field of film studies involves a wide variety of disciplines ranging from history to philosophy to sociology. According to the Writing Center at the University of North Carolina at Chapel Hill (UNCCH), one film can be analyzed in a number of ways and for this reason, there is no concrete universal method to writing a film analysis. The original foundations of film studies centered around a film's aesthetic elements but the rise of the women's movement allowed for a paradigm shift in the field. Since the 1970s, introductory books on film now focus on the growing degree of references to social and political issues in film study (Nichols, sec. 'To the Instructor'). Appropriately, this research incorporates visual film elements and a cultural approach by using both contextual and textual factors as a basis for analysis.

Overall, feminist theory was chosen for this research because of its ability to establish a connection between the narratives of the science-fiction film genre and modern feminist culture. Feminist film theory refers to a sociological approach that analyzes how gender differences construct meaning in a film (Smelik, 1). The early stages of feminist theory stemmed from premises about Freudian psychoanalysis that focused exclusively on sexual differences. Today, it is an approach aimed at understanding how cinema incorporates cultural practices to allude to a broader message involving the dichotomy between male and female as well as the role of women in film. Feminist theories are useful for interpreting the progression of females in the $\mathrm{MCU}$, their importance for emerging characters and their evolving stories, and the impact of popular culture on the production of Marvel Studios' films for Phase Four. 


\section{Findings and Analysis}

\section{Pepper Potts}

From her debut in Iron Man, Pepper exhibits traditional maternal qualities by taking care of her self-indulgent boss, Tony Stark. In the viewer's eyes, her role as "secretary" (Figure 1) is synonymous with "caretaker". She is often submissive to Tony's wishes despite his poor treatment of her and by Iron Man 2, she developed an intimate relationship with Tony - the sole reason he promoted her to CEO of Stark Industries. Her high-ranking position in the business industry, as well as her social life, stems entirely from Tony's sexual interests towards her, alluding to the fact that she lacks genuine leadership and management qualities (DeMarchi, 34). In a real-life situation, the CEO of a company would hold the power to make any executive decisions. However, Pepper is constantly turning to Tony for approval. In The Avengers, her name is not listed on any of the company's leases, but Tony's name is. In Iron Man 3, she is approached by Aldrich Killian about a project for Stark Industries but she rejects his proposal because Tony would not approve even though her decisions should not require his consent. As revenge for her rejection, Killian kidnaps Pepper and transforms her into a temporary superhero with powers. This alter ego enables Pepper to fight back against Killian and kill him, a feat Tony could not achieve. After the fighting is over, Tony reassures her that he can "fix" her and make her "normal" again, an egotistical power move he uses to repair a sense of threatened masculinity because a woman accomplished what he could not. Pepper sees no issue with this, overlooking the fact that Tony failed to even thank her for saving their lives. Her superpowers are quickly removed, Tony's ego is restored, and Pepper is once more the ordinary girlfriend. This scene reinforces the belief that superpowers belong in the hands of men while women are better suited for domestic duties.

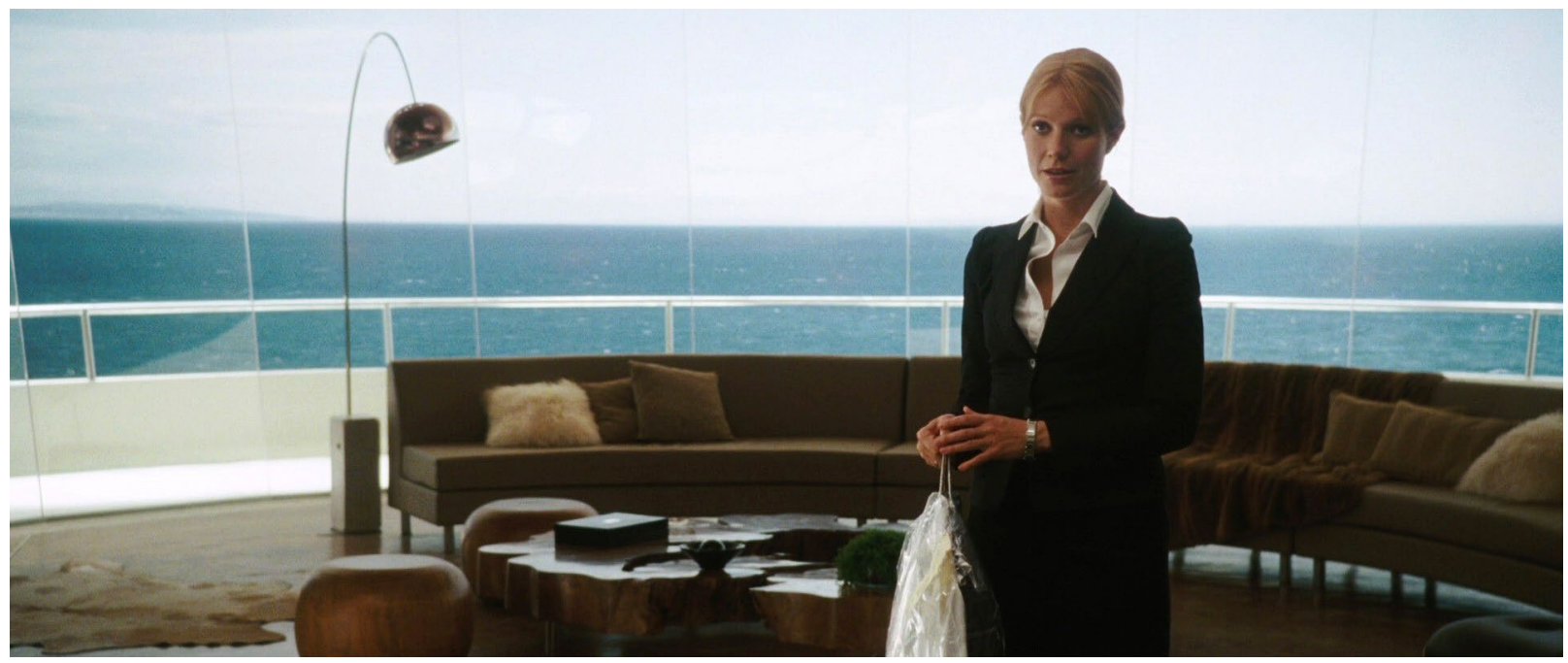

Figure 1. Pepper Potts as Tony Stark's secretary.

In the final scene of Spider-Man: Homecoming, Pepper makes a short appearance when Tony suggests that they should get married (Figure 2). In Avengers: Infinity War, they briefly discuss the possibility of having kids but it is not until Avengers: Endgame that Pepper makes a significant appearance once again. By the beginning of the latest film in the Avengers series, the couple has a young daughter and Pepper urges Tony to give up the role of Iron Man to focus on their family. Tony ignores Pepper's wishes as he's done in the past and joins the Avengers in their fight against Thanos. In the intense fight scene, Pepper makes a grand return to the screen as the superheroine "Rescue," costumed in a suit that parallels that of Iron Man (Figure 3). She fights bravely alongside her fellow females for the first time, supported with superpowers and a spirit of autonomy. However, Pepper's glorifying moment does not last long because when Tony yields the Infinity Gauntlet for himself, his body is unable to withstand its destructive power. In a heart-wrenching scene, Pepper returns to her nurturing self that viewers witnessed in the first Iron Man movie, 
comforting Tony prior to his death. She assures him that their family will "be okay" in the same way that he assured her that she would "be okay" in Iron Man 3 (02:33:35). The audience is left with an image of a widowed Pepper-a heartbroken, single mother. As a whole, Pepper Potts' character development is dependent on that of Tony Stark's. Marvel fails to develop Pepper as a prominent female role by not letting her take control of her own life, thus endorsing the belief that it is satisfactory to subject a female's identity to the command of a male, even when the title of CEO should imply she holds all the power.

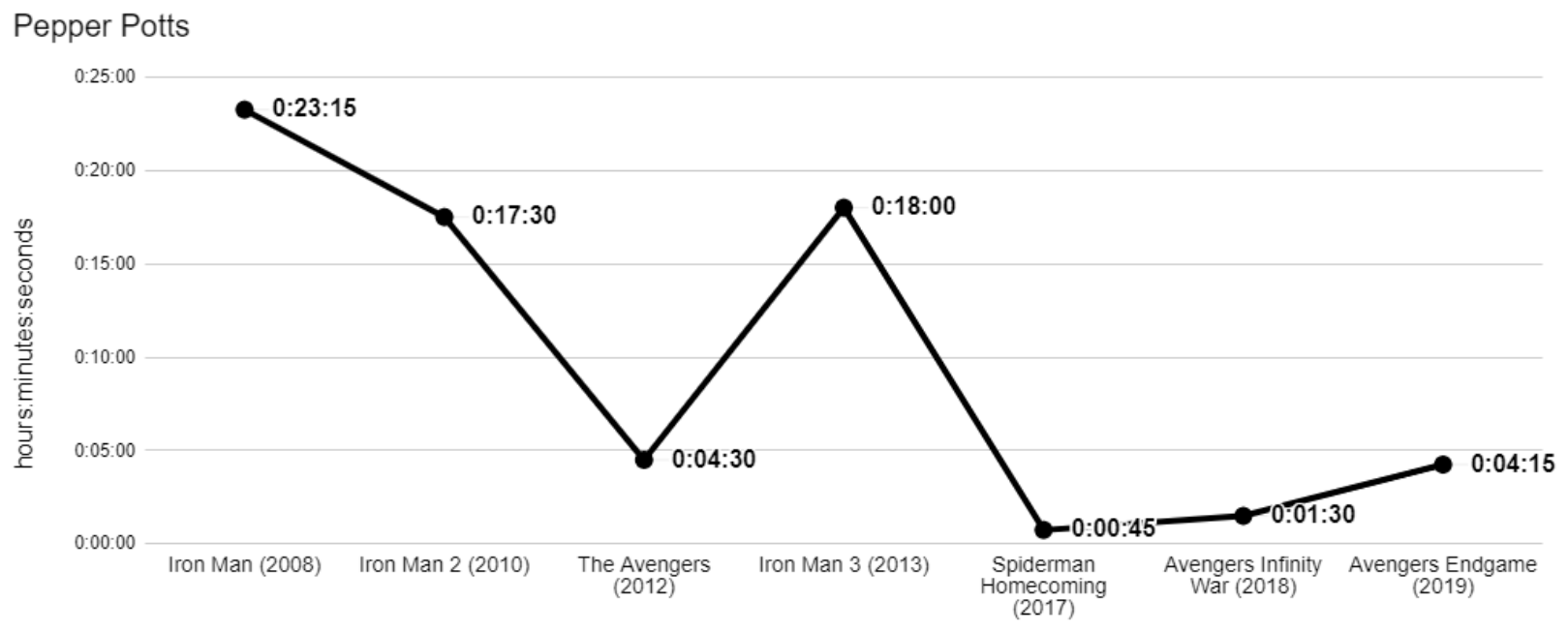

movies appeared in

Figure 2. Pepper Potts' time on-screen per movie.

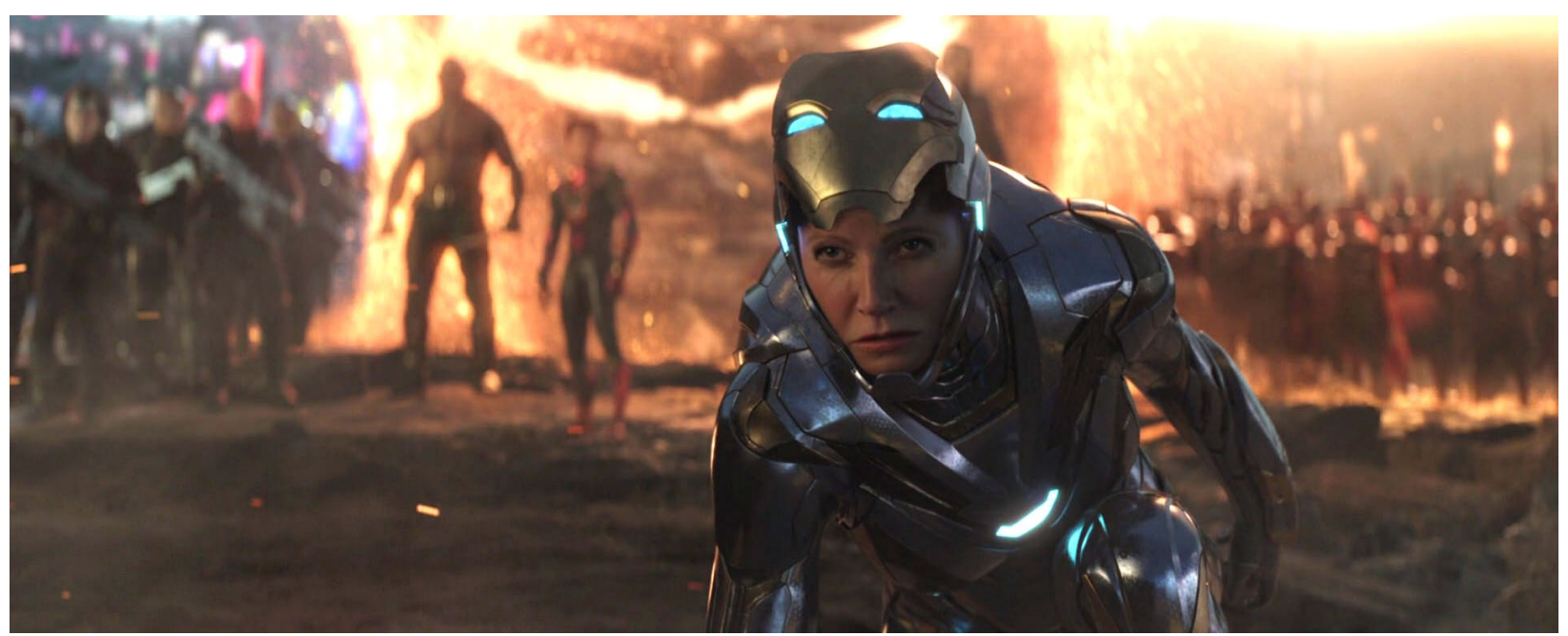

Figure 3. Pepper Potts as the superheroine "Rescue".

\section{Black Widow}

Natasha Romanoff makes her MCU entrance disguised as a notary in Iron Man 2 to capture the attention of Tony Stark and recruit him for the Avengers Initiative. She quickly reveals herself to be Black Widow, a Russian spy who " ...has no superpowers [or] super-powerful suits; she is simply a trained fighter who takes advantage of her gender" (Bateman, 1). The idea that Natasha does not actually hold any real superpowers reinforces the previously mentioned 
underlying notion from Iron Man 3 that women are not fit to be superheroines. One might even argue that her lack of powers makes her undeserving of the "superheroine" title.

Physically speaking, Natasha's body is exploited through a revealing and low-cut uniform that suggests that a woman at work of any kind is at risk of being objectified by a male onlooker (Gerard and Poepsel, 48). Paired with her striking red hair, Natasha is viewed as a sex object in a costume that draws attention to her curvy figure. She sometimes uses her looks to her advantage; for example, in an early scene in The Avengers she seduces then fights her way out of captivity by Russian enemies. Black Widow's visual appearance also works to make her a love interest to a few of her fellow male Avengers throughout the various films. Most notably, in Avengers: Age of Ultron, Black Widow and Bruce Banner have a flirtatious conversation in which he calls himself a monster, referring to his green alter ego, the Hulk. In return, she explains to him that during her training as a Russian spy, she was sterilized so that she could concentrate on her missions. She asks Banner if he still thinks he's the only monster on the team, implying that females who are unable to have children are monsters. Maternalist thinking involves the belief that exhibiting maternal qualities equates to morality and good character (Joffe, 14). In other words, maternalism is the notion that the only way to be a moral and decent woman is to have children. Natasha's remark about her infertility highlights Marvel's acceptance of the concept of motherhood as a necessity for female identity. This belief could be interpreted by viewers as correct, therefore contradicting the entire basis of all four waves of feminism.

Black Widow's storyline is cut short in Avengers: Endgame (Figure 4) when she and longtime male companion Hawkeye are sent to the planet Vormir to retrieve the Soul Stone, one of six Infinity Stones that when used together can wreak havoc on the universe. Upon their arrival, they learn that a sacrifice must be made to access the stone: one of them must die. In a passionate scene, Natasha and Hawkeye fight against one another, each not wanting to let the other die. In the end, Black Widow overpowers him, sacrificing herself by jumping off a cliff to her death. Not only does this leave the final fight scene as a predominantly male event, but killing her off was a bold choice for the movie's directors considering her importance as the only female Avenger. Unlike Tony, who received an extensive funeral scene, Natasha's death is grieved over for a single moment then her character's significance throughout eight movies is forgotten. All in all, Natasha Romanoff has yet to become a powerful, well-developed female-sacrificed to make way for Marvel's emphasis on hyper-masculinity and sexism.

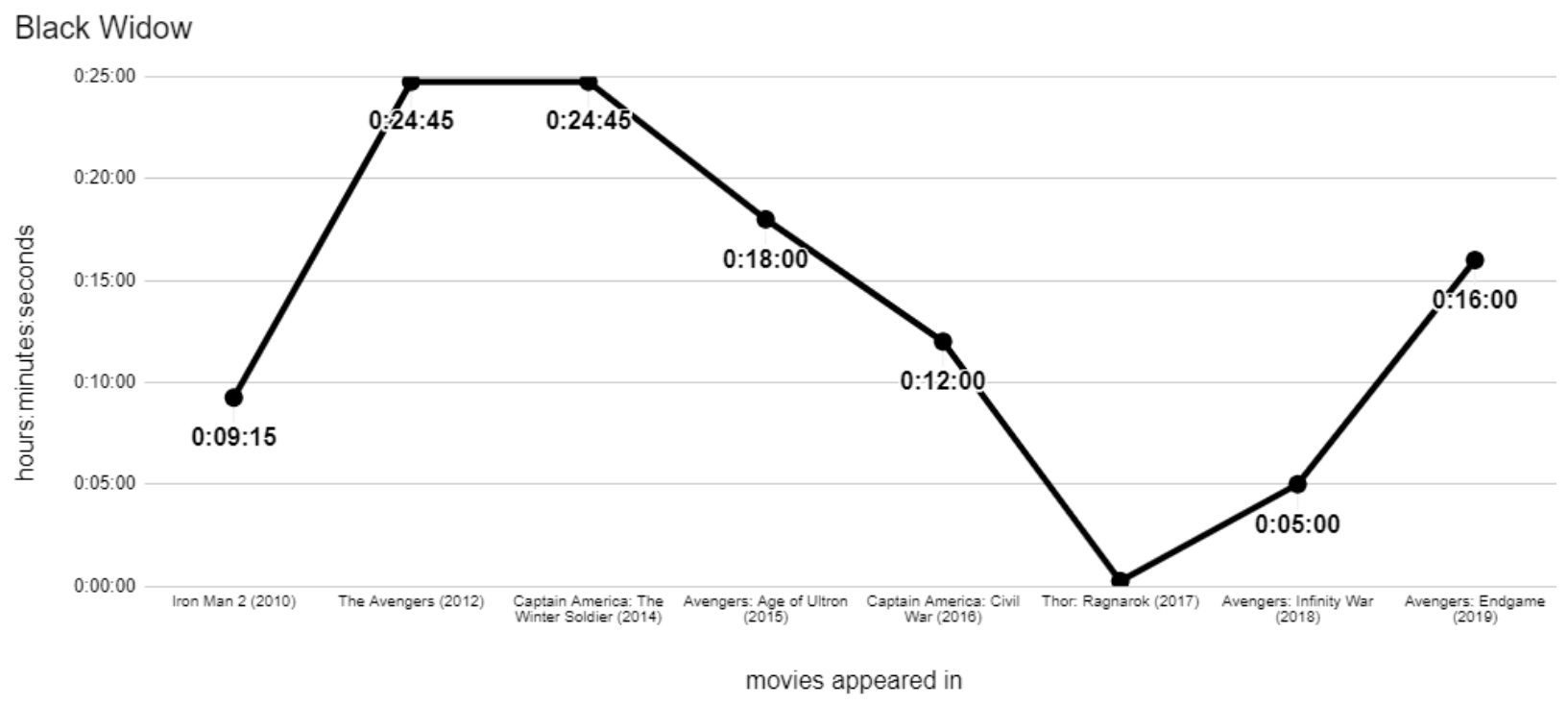

Figure 4. Black Widow's time on-screen per movie 


\section{Scarlet Witch}

Despite being the most powerful and valued character in all of the MCU, Wanda Maximoff still falls victim to a unique kind of sexual injustice. Beneath her multifaceted powers, lies an orphaned and emotionally unstable identity that makes her vulnerable in all the wrong moments. In her debut in Avengers: Age of Ultron she is young and "enhanced", as Captain America describes her (00:09:38), and Marvel Studios does not hold back in emphasizing this kid-like image for all her appearances from thereon out. As Robyn Joffe, a student at York University whose thesis focuses on gender and sexuality in film, points out "Scarlet Witch single-handedly paralyzes the Avengers" (10) then stops a moving train with her magic powers. Yet, after she teams up with the Avengers, she is the only one to breakdown during the climactic fight scene leading Hawkeye, whose only real skill is using a bow and arrow, to give her a pep talk in an abandoned building. Her reliance on male, parental-like figures only grows stronger after the death of her twin brother, who she depended on for comfort and emotional stability. In Captain America: Civil War, the trend continues when her reckless actions result in the death of innocent civilians but she is continuously absolved of any guilt by the male Avengers. They treat her like a child and never let her take responsibility for her actions, building a reliant character that is powerless where it truly matters. Avengers: Infinity War finally acknowledges her extreme power but not before portraying her as a damsel in distress. Towards the beginning of the film, her and her love interest, a superhero known as Vision, are attacked and reasonably speaking, her powers alone should be more than enough to overtake her attackers. Instead, Captain America ends up being the one to rescue her. In the directors' commentary for the film, brothers Anthony and Joe Russo openly admitted to crafting the scene in such a way that would give Captain America a "great entrance" thus casting Scarlet Witch's capabilities aside once again. For her latest role in Avengers: Endgame, she confronts Thanos, the villain that killed Vision in the previous film. As she unleashes years of abandonment and grief onto Thanos, this emotional but short-lived appearance (Figure 5), is the first time she acts independently of the other Avengers.

\section{Scarlet Witch}

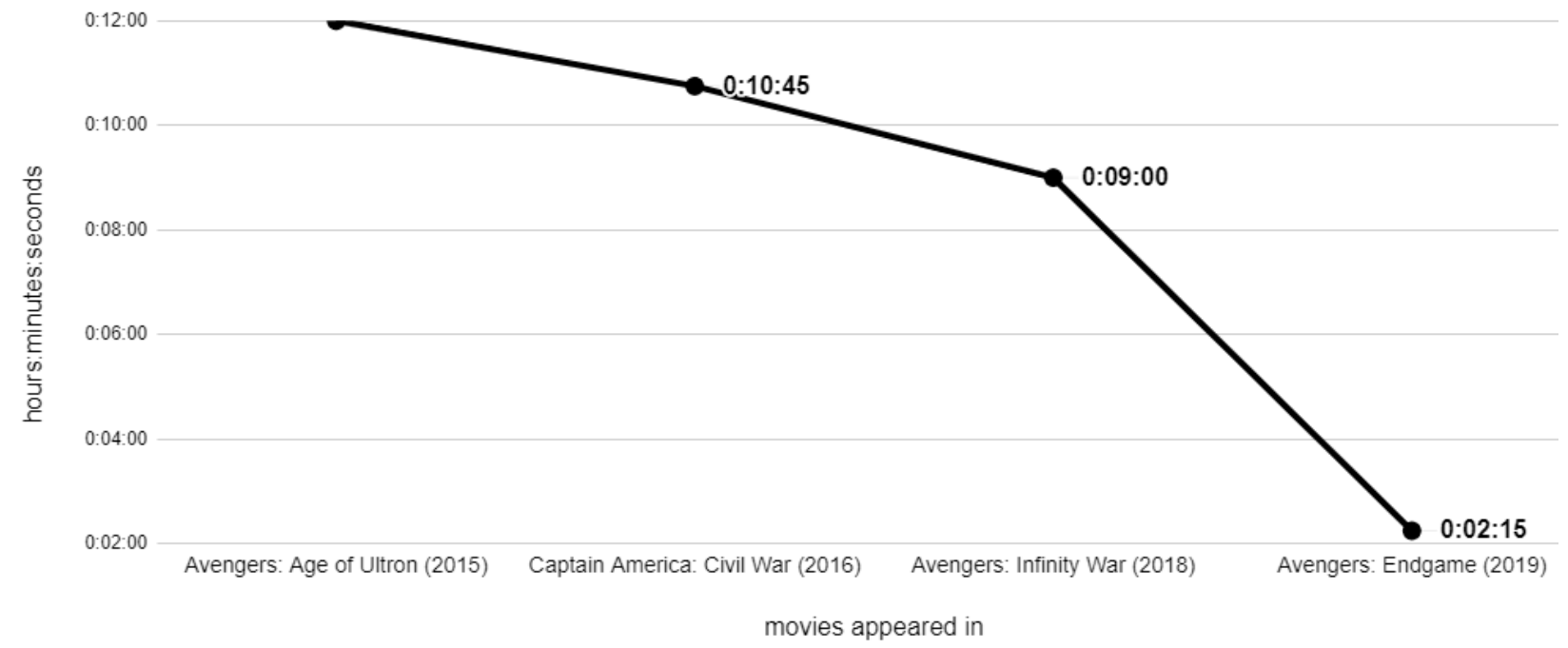

Figure 5. Scarlet Witch's time on-screen per movie

Overall, the infantilization - the treatment of a mature individual as a child —of Scarlet Witch severely undermines her superpowers of telekinesis and mind control. As she develops, she experiences more emotional conflicts that correlate to the growth of her power and consequently her dependency on others. Her characterization is indicative of the idea that she lacks the confidence to control such abilities on her own. By portraying her this way, the Russo brothers allow their audience to remain wrongly fixated on captivating stories of female fragility where a man can step in to save the day. 


\section{Gamora}

Like Black Widow, Gamora is set apart by being the only female in a group of intergalactic misfits known as the Guardians of the Galaxy. In Guardians of the Galaxy, she is frequently sexualized through dialogues with other characters and visual depictions. At one point during the film, Rocket (a male raccoon who is a member of the Guardians), implies that she trades her attractive looks for escape supplies from prison guards, a suggestion to which she replies "you must be joking" (00:34:32). Later on, Peter Quill (leader of the Guardians) attempts to flirt with her but she rejects his advances and dismisses his "pelvic sorcery" (00:52:28). A third male later calls her a "green whore". This sexist dialogue is accompanied by a mesh, tight-fit, cleavage showing costume in both Guardians of the Galaxy and Guardians of the Galaxy 2 (Figure 6). The most striking costume comes at the end of her first film after the enemy has been defeated and fighting has ceased. While the lead male characters remain in their modest uniforms, Gamora changed into a tight leather top paired with a short skirt (not practical of a superheroine to wear) that shows off her legs (Figure 7). This costume change reinforces the concept of the male gaze, a psychoanalytical theory applied to feminist film theory stating that females in movies are dressed to appeal to the desires of a male's wandering eyes (Smelik, 2).

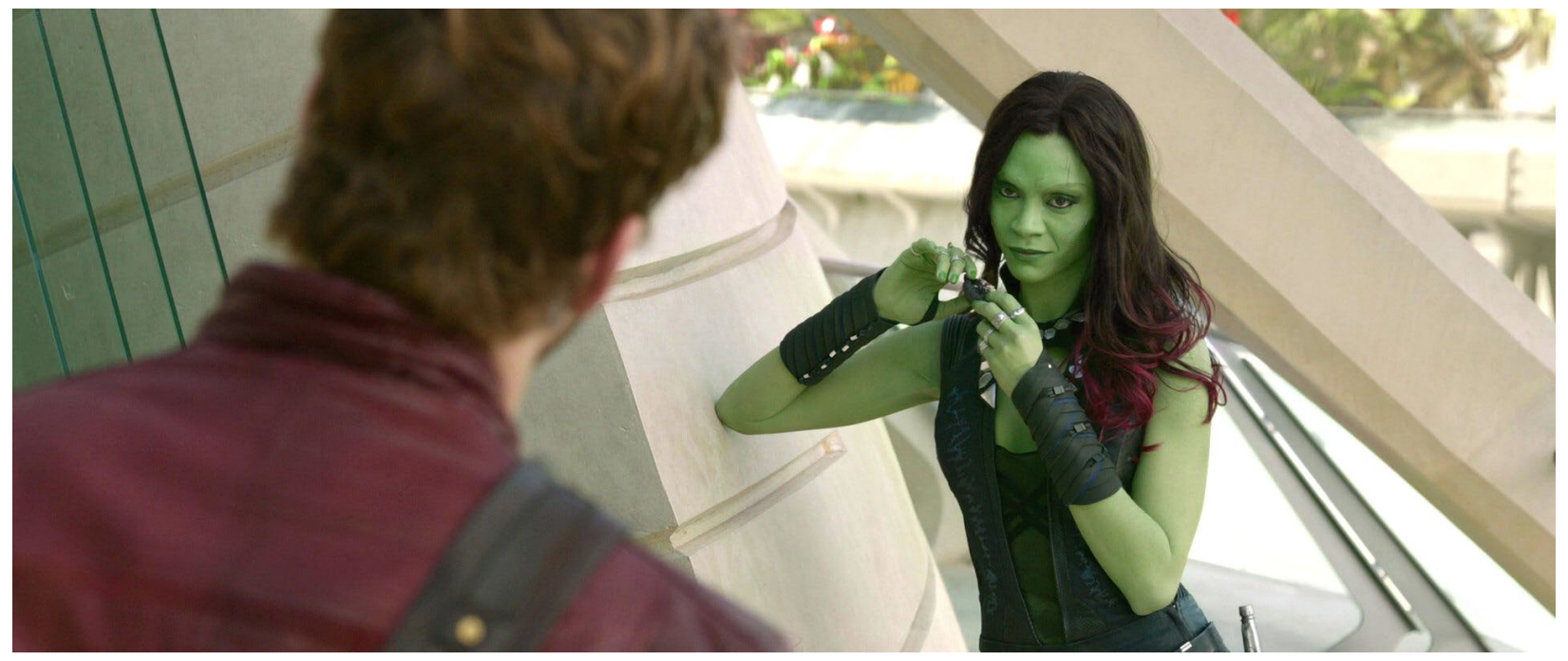

Figure 6. Gamora's mesh costume in Guardians of the Galaxy.

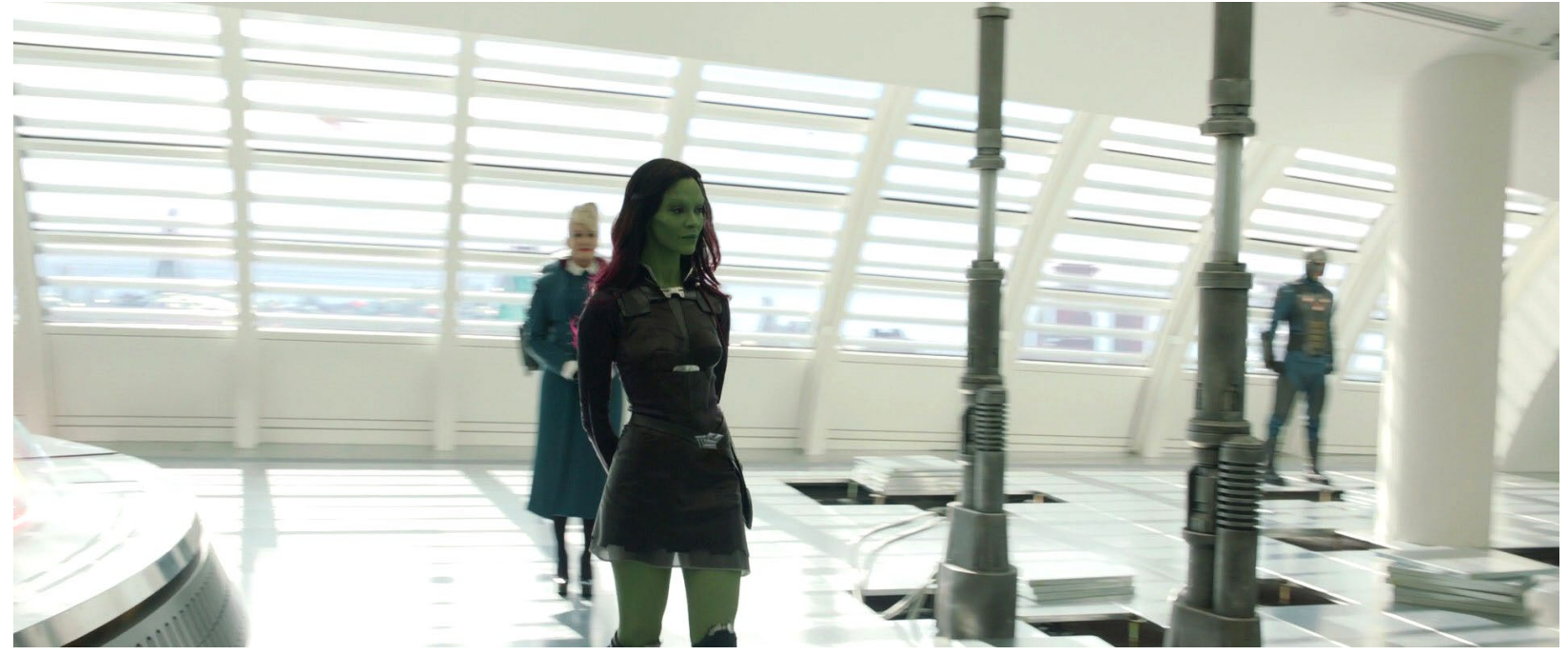


Figure 7. Gamora's costume changes to a skirt in Guardians of the Galaxy.

Gamora suffers a horrible fate when her life is taken in Avengers: Infinity War. As Thanos searches for the six Infinity Stones, he comes across the Soul Stone on the planet Vormir like Black Widow and Hawkeye later will. He and Gamora learn that in order for him to retrieve the stone, something that he loves must perish. At first, Gamora is relieved because she believes Thanos loves nothing and therefore cannot obtain the stone. Nevertheless, her own father turns against her in a tragic scene, pushing her off a cliff as her screams remain inaudible to the audience. Her lifeless body lies on the ground beneath, victim to a ruthless, cold-hearted father that adopted her into the universe just as quickly as he took her out. As a one-of-a-kind female character, Gamora's story was cut far too short simply in order to further develop an overarching male storyline. Like Black Widow, Gamora was a symbol of female strength in an otherwise male dominated group and their sacrificial deaths go to show how Marvel felt they had to die for a cause in order to be worth something. Although she makes a short appearance in Avengers: Endgame as her former self (Figure 8), her death scene implies that her entire arc served to contribute to that of a male, erasing years of progression into a powerful superheroine, negating her strength, and reducing her worth.

\section{Gamora}

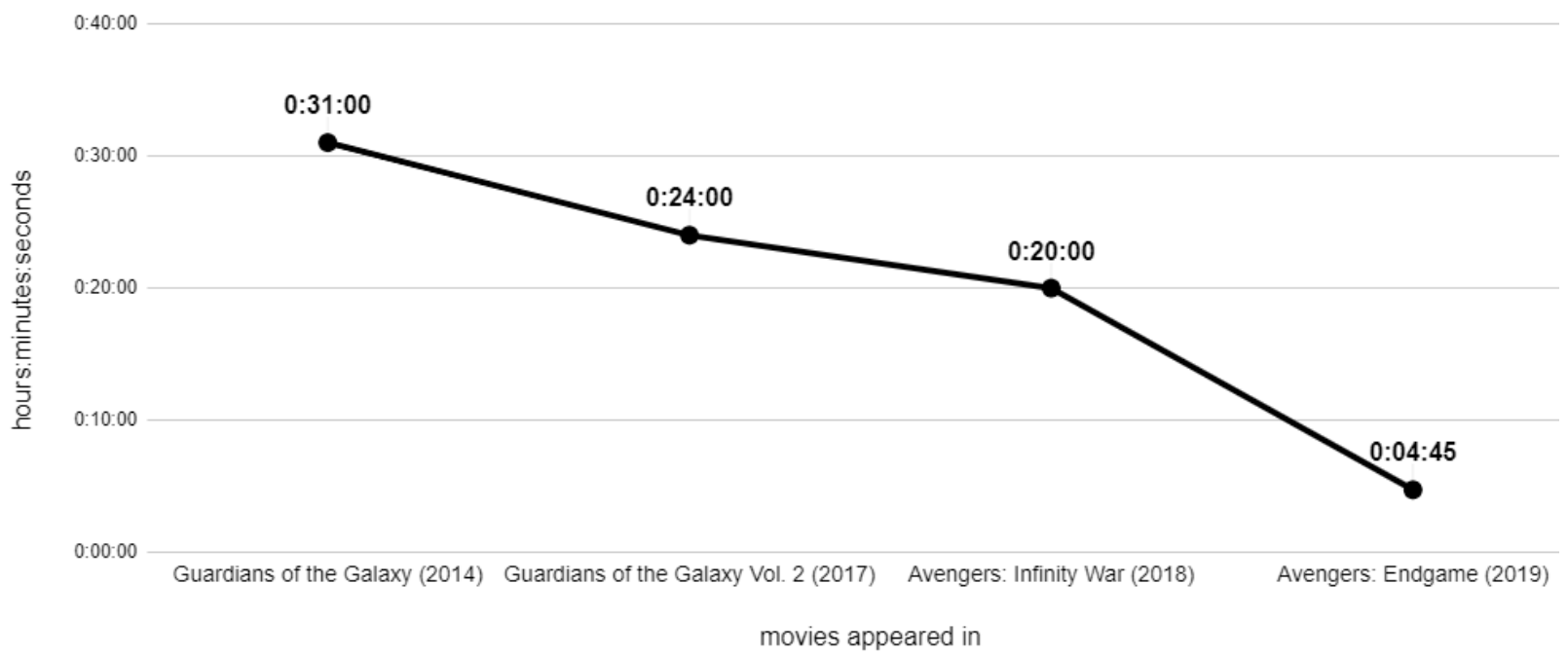

Figure 8. Gamora's time on-screen per movie.

\section{Nebula}

Gamora's adopted sister Nebula is portrayed as her direct opposite, filled with hatred towards Gamora as a result of their cruel upbringing. As children, Thanos forced the two to fight against one another and Nebula being the weaker of the two, would often lose. Whenever she lost, Thanos would punish her by removing pieces of her body such as the "brain from [her] skull and an arm from [her] body" (Bowen, 201). Eventually, Nebula's body would be made of biomechanical enhancements that render her one of the deadliest killers in the Galaxy. The tension between Nebula and her sister carried well into their adult years as the urge to defeat her in a fight increased. Despite her physical strength, Nebula is represented as a dependent and weak character who is submissive to her father. She remains loyal to him out of fear that she would be reduced to scrap pieces of metal if she did not comply with his wishes but also possesses the ulterior motive to kill him for the pain he has caused her. Nebula's envy of Gamora blended with resentment for her father are the only two characteristics uniquely attributed to her, making for a flat character that is weakly developed throughout her first two movie appearances (Kinnunen, 103).

The segregation between the two siblings is never officially resolved but after the death of Gamora in Avengers: Infinity War, Nebula is even more motivated to seek out Thanos and kill him. This translates into a dynamic 
character shift for Nebula as she teams up with the Avengers in Avengers: Endgame, resulting in a relatively large amount of screen time (Figure 9). In the end, Thanos is "snapped" from the universe, and Nebula emerges as a liberated antihero who for the first time, is able to experience empathy and victory with her fellow comrades. She ends up taking her sister's place in the Guardians of the Galaxy, paying homage to their broken bond. As a complex woman with deep internal conflict, Nebula's storyline speaks volumes from a feminist viewpoint by emphasizing her free will to overcome abuse by a dominating male figure and regain control of her life.

\section{Nebula}

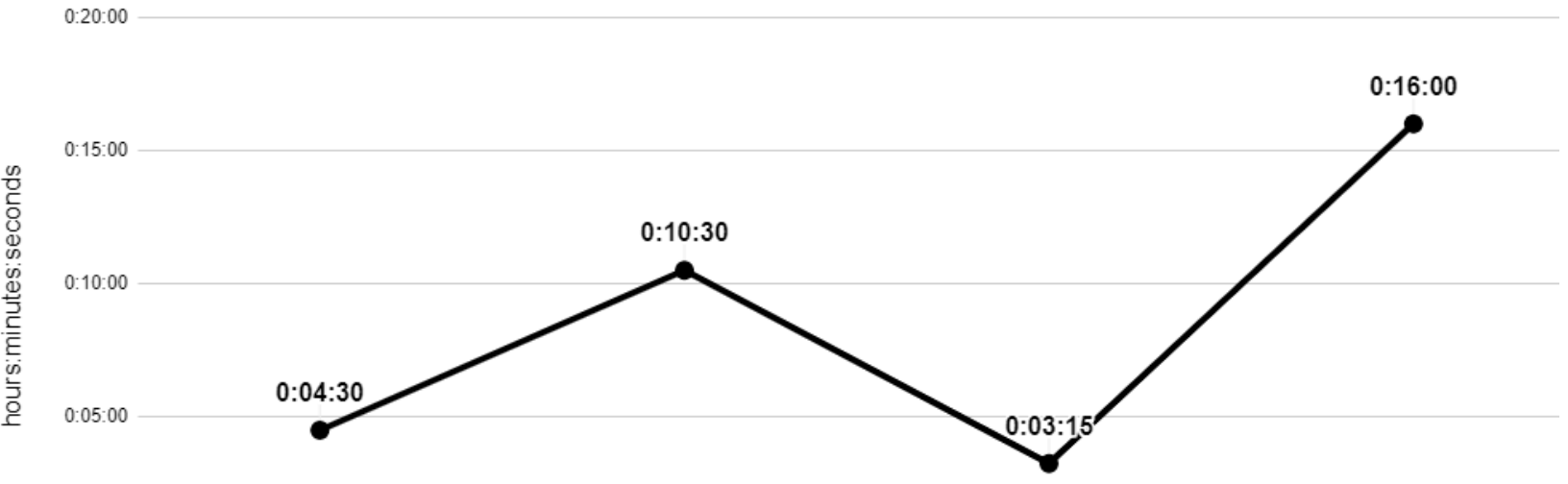

0:00:00

Guardians of the Galaxy (2014) Guardians of the Galaxy Vol. 2 (2017) Avengers: Infinity War (2018) Avengers: Endgame (2019)

movies appeared in

Figure 9. Nebula's time on-screen per movie.

\section{Captain Marvel}

From the beginning of her debut movie "Captain Marvel", set in 1995, Carol Danvers is subjected to an emotionallydriven storyline controlled by her male counterparts. In the opening scenes of the film, she fights her mentor Yon Rogg as a means of training. She tries to use her powers to fight back but he tells her to control them because "there is nothing more dangerous to a warrior than emotion" (00:03:14). As the movie progresses, we see flashbacks to her time in the U.S. Air Force boot camp. During her training as a pilot, the men in her class tease her that she is not strong enough and she is too emotional. One man notably tells her, "you do know why they call it a cockpit, don't you" (00:15:46) alluding to the widely held belief in the film that because she lacks a male sex characteristic, she cannot be a pilot. What she later finds out is that her powers were under constant control by Yon Rogg and could be taken away from her at any time. He claims that he made her the best version of herself because, in his eyes, she did not have the strength to control herself (01:27:57). The most pivotal moment of the movie comes when she finally breaks free from the brainwashing of Yon Rogg and unlocks her full potential. The scene marks the first time where Captain Marvel is seen as a superhero with true strength and not just a woman with emotional struggles. Fueled by rage, Captain Marvel fights Yon Rogg as, by no coincidence, the song "I'm Just a Girl" by No Doubt plays in the background. By the end of the movie, Yon Rogg is banished to Earth but not before he attacks Danvers once more by asking " can you keep your emotions in check or will they get the better of you" (01:44:32). Captain Marvel may be the first female-centered MCU production but the narrative of the film continuously portrays both pilot Danvers and Captain Marvel as an emotional female who must operate under the control of a man. Captain Marvel is not only a step backward in female inclusivity for Marvel Studios because it fails to let the female-led story stand on its own, but it presents femininity as a weakness that must be overcome before one can perform the same jobs as a man (Joho).

Captain Marvel makes her second and latest appearance in the MCU for a mere total of 6 minutes in Avengers: Endgame (Figure 10). As the Avengers prepare for their fight against Thanos, she joins them on Earth empowered by a renowned sense of independence, confidence, and a new short, pixie-cut hairstyle (Figure 11) that 
suggests Marvel's decision to mold Captain Marvel into the stereotypical male superhero persona. Although she disappears for the majority of the movie, Captain Marvel returns as a powerful asset in the final fight scene, saving the Avengers army from defeat and arguably being the sole reason they defeat Thanos. The evolution of Captain Marvel from a submissive, identity-conflicted female to a key superheroine that defies male objectification is evidence of an attempt for female empowerment but only begins to scratch the surface.

\section{Captain Marvel}

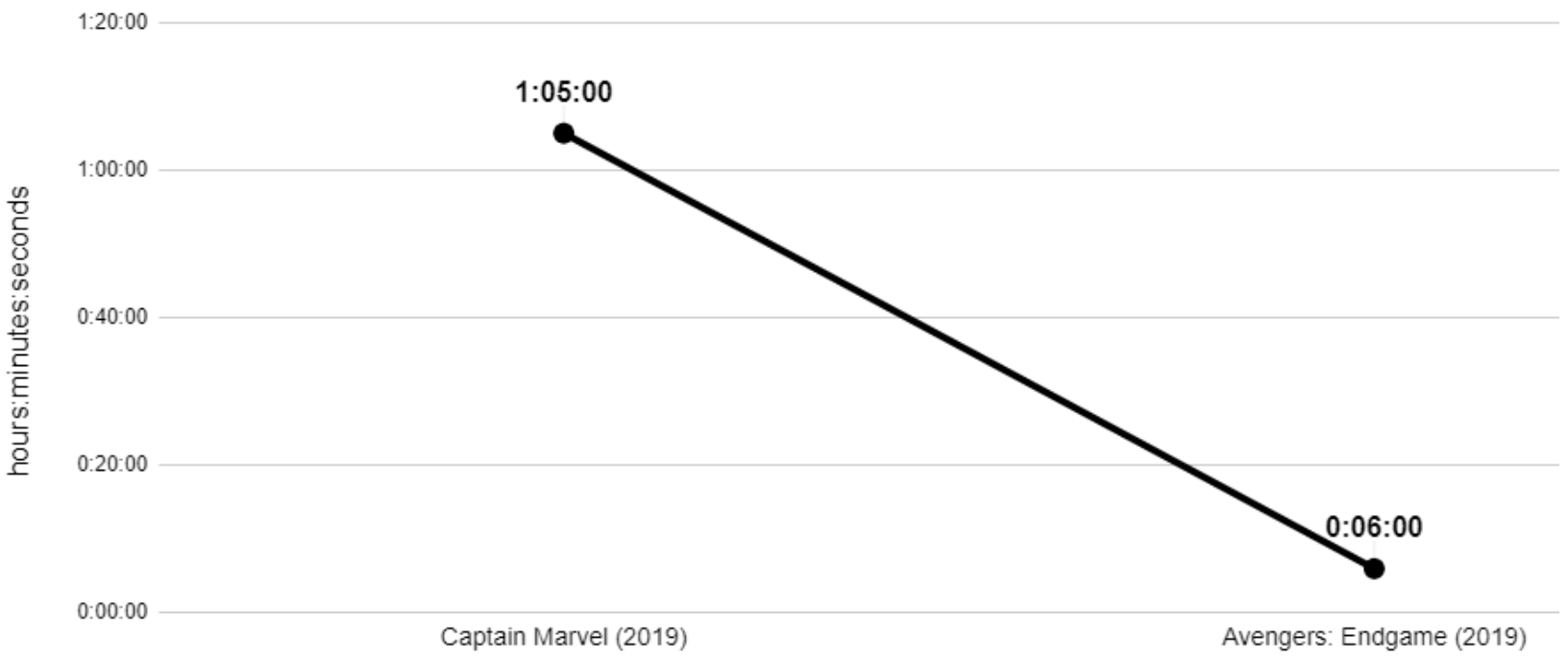

movies appeared in

Figure 10. Captain Marvel's time on-screen per movie.

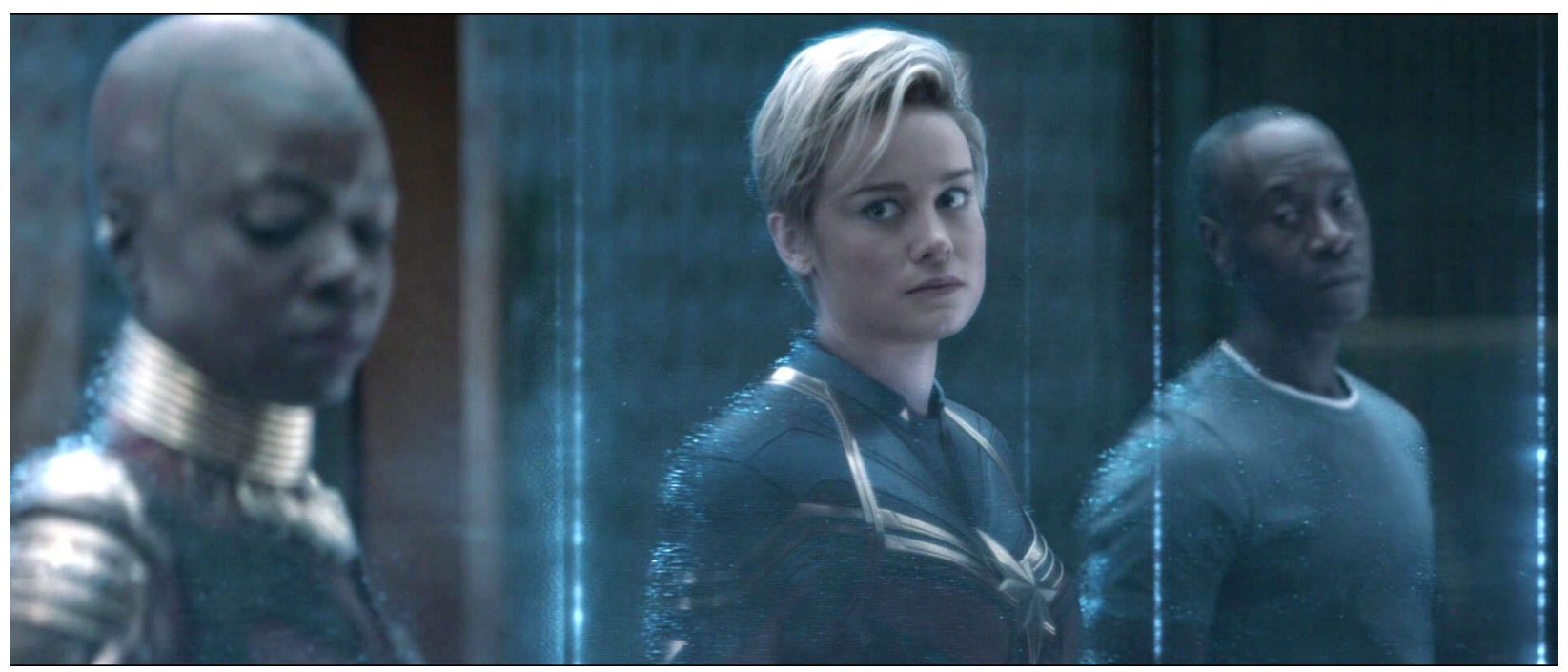

Figure 11. Captain Marvel's (center) pixie-cut in Avengers: Endgame.

\section{Tokenism}

For my concluding analysis, I considered the influence of two noteworthy fight scenes in Avengers: Infinity War and Avengers: Endgame. In Avengers: Infinity War, Scarlet Witch finds herself helpless against a member of Thanos' army. All of a sudden, she is joined by female superheroes Okoye - the loyal leader of the Dora Milaje, the all female army who serve as the bodyguards of the fictitious African nation, Wakanda—and also Black Widow who notes that 
"she is not alone" (01:55:41). Similarly in Avengers: Endgame, Captain Marvel is about to be outnumbered by Thanos' aliens when her female partners rush to her aid just in time (Figure 12). "She's got help," one of them dramatically states (02:27:08) as the group launches an attack on their enemy, only to be taken down seconds later.

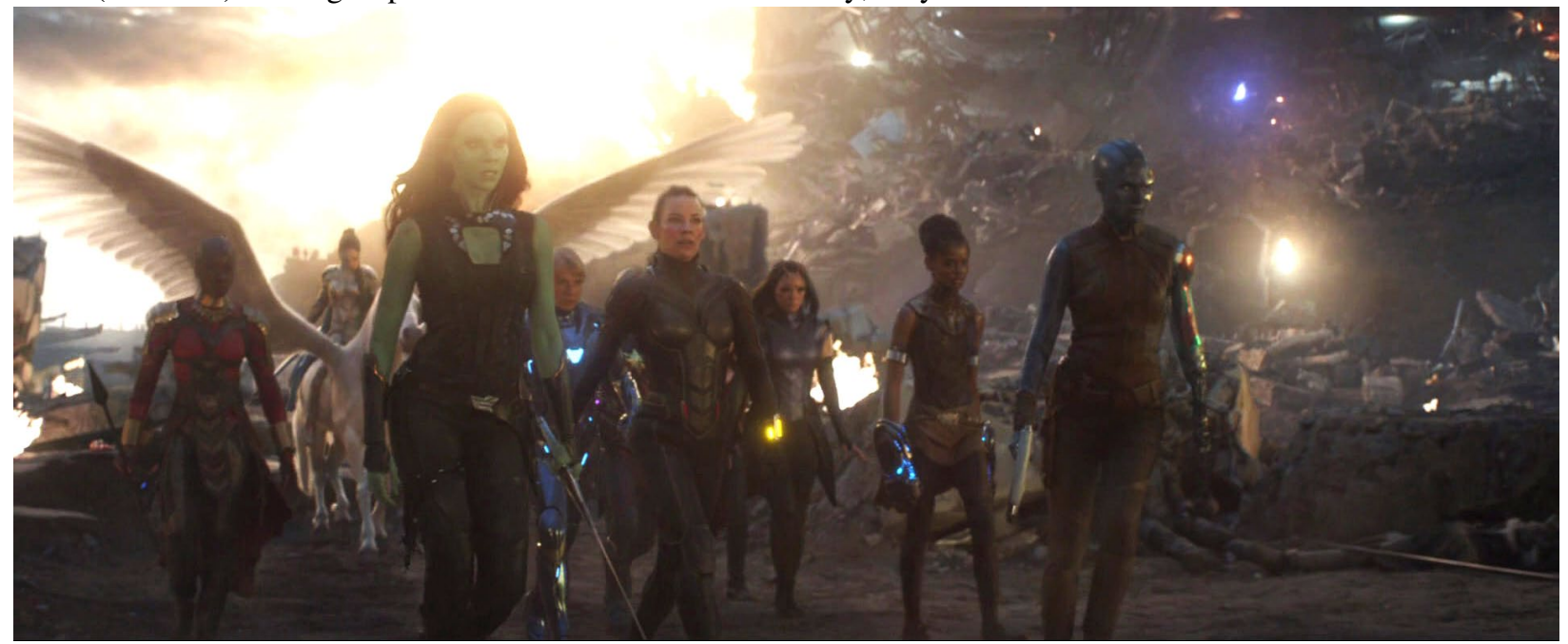

Figure 12. The all female fight scene in Avengers: Endgame.

The lack of men in these scenes raises the question of what the directors' intentions were in showcasing the female lineup of the MCU just for them to be defeated. From a plot perspective, why were only females readily available to help during those moments when defeat was eminent? Aside from the logical flaws, the scenes can be seen as clear examples of tokenism, "the practice of making only a symbolic effort to do a particular thing, especially by recruiting a small number of people from underrepresented groups in order to give the appearance of sexual or racial equality within a workforce" (Sherrer). In Marvel's case, they execute tokenism by making these scenes feel forced and patronizing to viewers, as opposed to celebratory for female inclusion. Cinematic female inclusivity should be an organic and natural statement that makes a meaningful addition to the film's plot. Neither scene offers significant contributions to the overall narrative of its film, leaving the final fate of the battle in the hands of Marvel's superstars: the men. These scenes may have been meant as striking moments of girl power but instead came off as pandering efforts to put females on the front lines for viewer applause.

\section{Conclusion and Future Directions}

My findings and analysis show that Marvel Studios' lack of equal representation for their female characters in all aspects of the science-fiction film genre, including superpowers and costume design, has gone heavily unnoticed in Phases One through Three. Rather than integrating female power with male power, Marvel Studios ended the storylines of two key female characters, suggesting that males and females cannot be equally capable in the same universe. Their efforts to disguise tokenism as female inclusivity, by including all-female fight scenes, were overdramatized and insufficient in an attempt to make up for years of female marginalization.

In the context of the comprehensive field of film studies and its societal impact, the implications of this research are that the power of female roles is heavily undermined and sexualized not only in the MCU but for films in general. In the viewer's eyes, these films uphold a patriarchal structure and reinforce social norms that objectify women in their workplace and elsewhere. Being the highest-grossing film franchise of all time and notably one of the most popular, the MCU sets an example not only for their competitors but for their female audience as well. Even though they are fictional, these representations mold cultural standards of female identity that influence behavior. Future studies could attempt to gain more detailed insight from people directly involved in the filmmaking process, such as producers and costume designers, in order to more fully grasp an understanding of female marginalization in 
film. It is urgent that Marvel and other franchises in the media industry re-examine their portrayal of females and take actionable measures to reform their roles to fully respect their importance.

Considering the Fourth Wave feminist movement circulating through social media, it is fitting that Marvel is finally taking the necessary steps to potentially portray women properly in film. The MCU will begin Phase Four with its second female-led film, Black Widow, set for release on November 6, 2020. The movie is a biography of the late Black Widow to explain her history as a young Russian spy and her broken relationships with family. As for television, Scarlet Witch will also be getting her own miniseries/sitcom, "WandaVision". Coming in December 2020, the show is set in the 1950s as Wanda lives as a housewife with her partner Vision. One might wonder if portraying her as the stereotypical housewife, an image that the Second Wave Feminism strived so hard to erase, will overshadow her immense power or allow her characterization to break free from a male-oriented storyline. Other female-focused productions in the works include "Ms. Marvel", "Agent Carter", "SheHulk", and Captain Marvel 2. Together, while these female-centered productions are a product of Marvel's growing response to Fourth Wave Feminism and might be a step in the right direction, there are still long ways to go before females in the ever-expanding universe of Marvel are truly liberated.

\section{Acknowledgments}

I would first like to thank my AP Capstone Research teacher, Ms. Echezabal for her continuous support and mentorship. I would also like to thank the college professors who provided me with insight on my project. Lastly, I would like to thank my friends and especially my family for supporting me through long nights of research. This would not have been possible without all of you!

\section{References}

Bateman, D. (2015). The Avengers. Science Fiction Film and Television, 8(2), 285-289. Retrieved from https://search.proquest.com/docview/1694690466?accountid=192155

Black, Shane, director. Iron Man 3. Marvel Studios, 2013.

Boden, Anna and Ryan Fleck, directors. Captain Marvel. Marvel Studios, 2019.

Bowen, Daniel Huw. “I Hope Daddy Isn't as Big of a Dick as You': Guardians of the Galaxy Vol. 2, Fatherhood and Its Legacy." Fantasika Journal, vol. 1, no. 2, Dec. 2017, pp. 199-202.

Burkett, Elinor, and Laura Brunell. "The Fourth Wave of Feminism.” Encyclopadia Britannica, Encyclopædia Britannica, Inc., 16 Dec. 2019, https://www.britannica.com/topic/feminism/The-fourth-wave-of-feminism.

"Commentary," Avengers: Infinity War, directed by Anthony Russo and Joe Russo (Burbank: Marvel Studios 2018), Blu-ray.

DeMarchi, Mary Louise, "Avenging women: an analysis of postfeminist female representation in the cinematic Marvel's Avengers series" (2014). College of Liberal Arts \& Social Sciences Theses and Dissertations. 167. https://via.library.depaul.edu/etd/167

Dorey-Stein, Caroline. “A Brief History: The Four Waves of Feminism.” Progressive Women's Leadership, 28 June 2018, www.progressivewomensleadership.com/a-brief-history-the-four-waves-of-feminism/. 
Favreau, Jon, director. Iron Man. Marvel Studios, 2008.

Favreau, Jon, director. Iron Man 2. Marvel Studios, 2010.

"Feminist Film Theory." Film Theory, 6 Aug. 2015, www.filmtheory.org/feminist-film-theory/.

"Film Analysis." Writingcenter.unc.edu, writingcenter.unc.edu/tips-and-tools/film-analysis/.

Gunn, James, director. Guardians of the Galaxy. Marvel Studios, 2014.

Gunn, James, director. Guardians of the Galaxy Vol.2. Marvel Studios, 2017.

Hesse-Biber, Sharlene. "Qualitative or Mixed Methods Research Inquiry Approaches: Some Loose Guidelines for Publishing in Sex Roles.” Sex Roles, vol. 74, no. 1-2, Jan. 2016, pp. 6-9. EBSCOhost, doi:10.1007/s11199015-0568-8.

Jacobs, Christopher P. "Film Theory and Approaches to Criticism, or, What Did That Movie Mean?" University of North Dakota, 5 Jan. 2013.

Joffe, Robyn. "Holding Out for a Hero(Ine): An Examination of the Presentation and Treatment of Female Superheroes in Marvel Movies." Panic at the Discourse, 5 Apr. 2019, www.panicdiscourse.com/holding-out-for-aheroine/.

Joho, Jess. “Captain Marvel's Shallow Take on Feminism Doesn't Land.” Mashable, 9 Mar. 2019, mashable.com/article/captain-marvel-feminism-female-superhero/.=

Kinnunen, Jenni. "Badass Bitches, Damsels in Distress, or Something in between? : Representation of Female Characters in Superhero Action Films." University of Jyväskylä, Apr. 2016, https://jyx.jyu.fi/handle/123456789/49610.

“Marvel Characters, Super Heroes, \& Villains: Marvel.” Marvel Entertainment, www.marvel.com/characters.

“MCU Movies Screen Time Breakdown.” IMDb, IMDb.com, 2 July 2019, www.imdb.com/list/ls066620113/?sort=release date,asc\&st $\mathrm{dt}=\&$ mode=detail\&page $=1$.

Nichols, Bill. Engaging Cinema: An Introduction to Film Studies. New York: W.W. Norton, 2010. Print.

Poepsel, Mark, and Madelaine Gerard. "Black Widow: Female Representation in the Marvel Cinematic Universe." Polymath: An Interdisciplinary Arts \& Sciences Journal, vol. 8, no. 2, 2018, pp. 27-53., https://ojcs.siue.edu/ojs/index.php/polymath/article/view/3314.

Russo, Anthony and Joe Russo, directors. Avengers: Endgame. Marvel Studios, 2018.

Russo, Anthony and Joe Russo, directors. Avengers: Infinity War. Marvel Studios, 2019.

Russo, Anthony and Joe Russo, directors. Captain America: Civil War. Marvel Studios, 2016. 
Russo, Anthony and Joe Russo, directors. Captain America: The Winter Soldier. Marvel Studios, 2014.

Sherrer, Kara. "What Is Tokenism, and Why Does It Matter in the Workplace?" Vanderbilt Business School, 26 Aug. 2019, business.vanderbilt.edu/news/2018/02/26/tokenism-in-the-workplace/.

Smelik, Anneke. "Feminist Film Theory." The Wiley Blackwell Encyclopedia of Gender and Sexuality Studies, 21 Apr. 2016, pp. 1-5., doi:10.1002/9781118663219.wbegss148.

Waititi, Taika, director. Thor: Ragnarok. Marvel Studios, 2017.

Watts, Jon, director. Spider-Man: Homecoming. Marvel Studios, 2017.

Whedon, Joss, director. Avengers: Age of Ultron. Marvel Studios, 2015.

Whedon, Joss, director. The Avengers. Marvel Studios, 2012. 